\title{
OPEN FORUM AND READER RESPONSE
}

May 16,1975

Open Forum and Reader Response

Horizons, Journal of the College Theology Society

Villanova University

Villanova, Pennsylvania 19085

To the Editors:

In 'DRE's and 'The Bottom of the Barrel': Our Responsibilities" of the Spring 1975 Horizons, Professor Van Allen does well in calling attention to the problems of parish religious-education administrators.

He cites the generally low salary as a principal cause for DRE's changing their parishes of employment or leaving their profession. Two additional factors, however, contribute to the DRE's lack of steadfastness. Either he or she soon comes into policy or personality conflict with the pastor, or the parishioners express their confusion as to exactly what the DRE is supposed to be doing in his job.

An alleviation of all three factors and of the precariousness of which Professor Van Allen speaks can be attempted in at least two ways. First, the determination of the need of a DRE should be reached not by the pastor alone, for the latter is often not attuned to all developments in education. Rather, he should consult with both the staff of the parish school and with parishioners having interest in all aspects of education (private, public, child, and adult), liturgy, and finance, then have these persons interview the potential DRE. This would serve the purpose of detailing the capacities in which the DRE would function, would give the DRE a sense of commitment to the parishioners and pastor rather than to the pastor alone, would probably bring about a higher salary offer, and would provide a buffer group between the DRE and the pastor.

Second, the areas in which the DRE would have responsibility of decisions and consultation should be well publicized to the parish. His or her relationship to the parish school should be clearly defined, as well as his role with the rectory priests in handling adult education and CCD. The parish's money's worth could be gotten by extending the DRE's responsibility into the civic community by having him represent the parish to the local public-school district on, for example, its curriculum council, and represent educational matters to the local ministerial association. Then sufficient time-a minimum two years - should be given the DRE to allow his administrative ability to 
be felt in the parish. Finally, a method and representative group for evaluation of the DRE's performance should be agreed upon.

With this procedure, the DRE-be he or she religious or laywould hopefully gain greater job satisfaction, and the parish would benefit from its clear expectation of the DRE and from the improved quality of his service.

Sincerely,

Harvey Bollich

Director of Religious Education

Holy Family Church, Parma, Ohio

Lecturer in Theology

Saint John College, Cleveland, Ohio

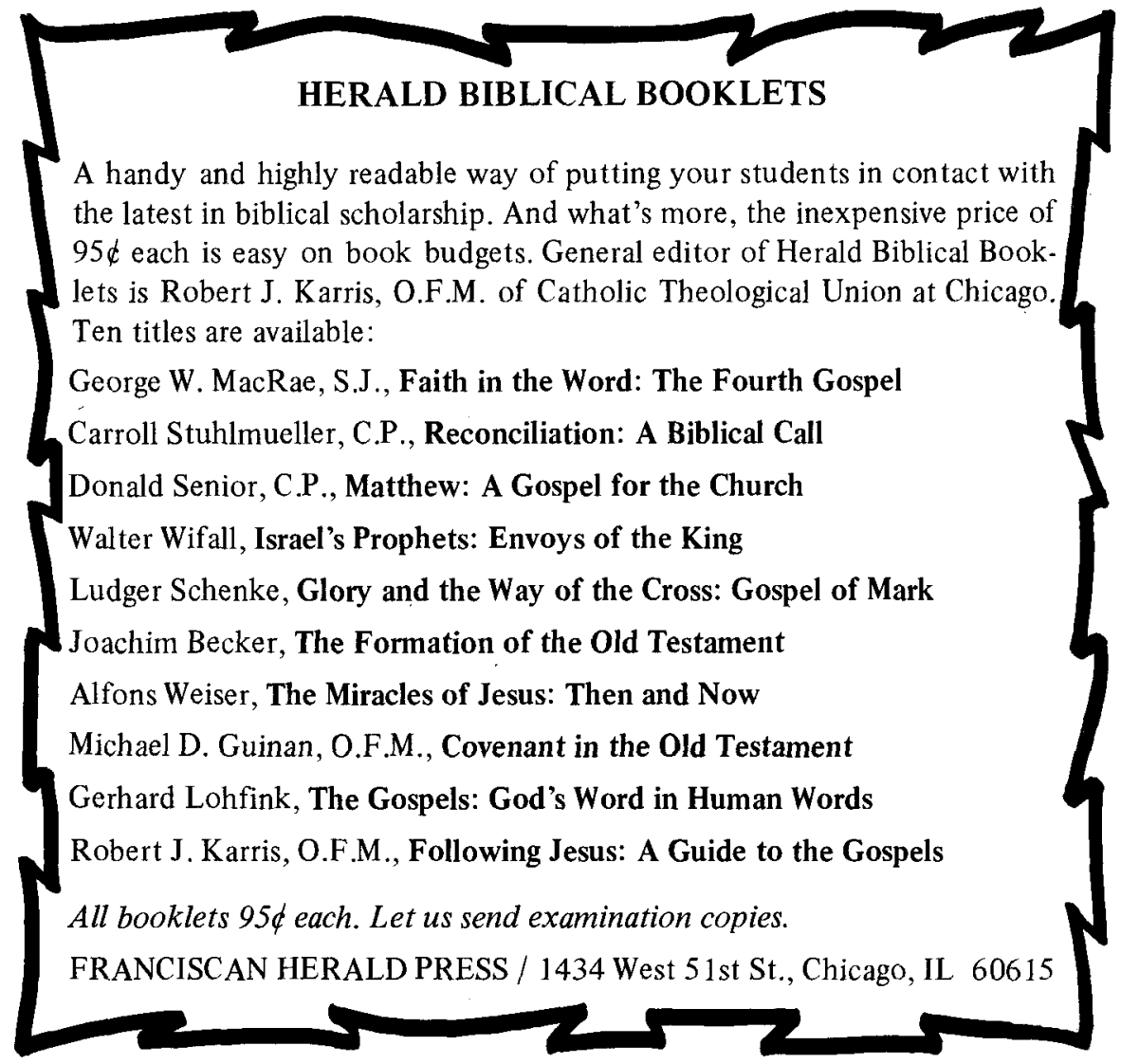

